\title{
Mysterious Prehistoric Samuel: Homo erectus paleohungaricus in the Context of Anthropogenesis
}

\author{
Václav Soukup ${ }^{1}$ - Zdenka Mechurová2 \\ 1 Institute of Ethnology, Faculty of Arts, Charles University, nám. Jana Palacha 2, 11638 Prague 1, Czech Republic \\ 2 College of International and Public Relations in Prague, U Santošky 17, 15500 Prague, Czech Repulic
}

Received $28^{\text {th }}$ July 2018; accepted $13^{\text {th }}$ November 2018

\section{ZÁHADNÝ PRAVĚKÝ SAMUEL: HOMO ERECTUS PALEOHUNGARICUS V KONTEXTU ANTROPOGENEZE}

ABSTRAKT Předmětem studie je analýza kosterních pozůstatků pravěkého hominina, které byly nalezeny před padesáti lety na území dnešního Madarska a klasifikované jako Homo erectus paleohungaricus. Cílem studie je zasadit objev tohoto hominina do kontextu současných názorů na vývoj archaického Homo sapiens a reinterpretovat jeho evoluční status v souladu s novými poznatky paleoantropologie. Zvláštní pozornost je proto věnována hypotéze, podle níž Homo erectus paleohungaricus představuje lokální variantu druhu Homo heidelbergensis.

\section{KLÍČOVÁ SLOVA Kulturní evoluce; Homo heidelbergensis; Homo erectus; Vértesszőlős; László Vértes}

\begin{abstract}
The object of the study is an analysis of fossil remains of hominin which were found before fifty years ago on the territory of today's Hungary and classified as Homo erectus paleohungaricus. The study aims to put this finding into context of current views on the evolution of archaic Homo sapiens and reinterpret its evolutionary status. Special attention is therefore paid to test the hypothesis according to which Homo erectus paleohungaricus represents a local variant of Homo heidelbergensis.
\end{abstract}

KEY WORDS Cultural evolution; Homo heidelbergensis; Homo erectus; Vértesszőlős; László Vértes

\section{INTRODUCTION}

Despite the considerable progress science has made over the past centuries, there is not a clear, generally valid and universally accepted interpretation of the evolution of man and the genesis of human creativity. It is much more honest to admit that the reconstruction of the course of anthropogenesis represents the constant gathering, updating, interpretation and reassessment of empirical data that constitutes the forever incomplete picture of human evolution.

Paleoanthropology primarily focuses on reconstructing the evolution of the human species. During the $20^{\text {th }}$ century paleoanthropologist managed to gather a large number of hominid fossils and prehistoric artefacts, which enabled them to reconstruct an increasingly accurate and better picture of human prehistory from the emergence of archaic African hominins, to the evolution of australopithecines and early members of the Homo genus (Homo habilis, Homo erectus, Homo ergaster) to the evolutionarily advanced representatives of the human species, such as Homo antecessor, Homo heidelbergensis and Homo neanderthalensis. The core of the paleoanthropological research consists of five basic methodological procedures that include:

1. Fieldwork, including prospecting, probing and the excavation of paleoanthropological and archeological finds.

2. The critical verification of the authenticity and reliability of archeological sources, including an assessment of the circumstances involved in acquiring them.

3. Laboratory processing of specific findings (artefacts and fossil remains), inventory, preservation, restoration and reconstruction. 
4. The description and analysis of finds, allowing for their classification (typology) and spatio-temporal classification based on stratigraphy, cartography and dating.

5. The synthetic interpretation and explanation, making broad use of interdisciplinary findings and theories from archeology, paleoanthropology, ethnoarcheology, prehistory, sociocultural anthropology, ethology, demography, sociology and ethnology (Soukup 2015).

In our view the hypothetical reconstruction of the evolution of the human species requires an interdisciplinary approach - the systematic use of findings from the broadest spectrum of various scientific disciplines. In addition to physical anthropology, paleoanthropology and prehistoric archaeology, genetics and ethology findings are playing an increasingly important role in interpreting prehistoric discoveries. The importance of genetics lies mainly in the fact that it managed to reveal and describe the mechanisms of biological evolution and the causes of the creation of species. Last but not least, paleogenetic methods have enabled us to determine the genetic and evolutionary relations to the closest relatives of the human species and to date important milestones of human evolution. Ethology, especially primatology, has significantly contributed to a deeper understanding of the behavior patterns of prosimians, monkeys and apes. In reconstructing the individual phases of the evolution of primates and hominins, this enables us to use analogy methods and to formulate hypothesis on the potential behavior patterns of our animal predecessors.

The principle of adaptive activity is a basic attribute of the existence of all biological life forms. Such activity can generally be defined as the information-geared activity and interaction of living systems with an external environment aimed at the survival of the given organism. Naturally, human activity is stimulated, programmed, coordinated and carried out via a mechanism that is wholly unique in the animal kingdom - culture. This is the category of supra-biologically created means and mechanisms, through which the members of the Homo genus recreate external nature and the social world. Culture as a supra-biological way of adapting the Homo genus to an external environment differs from biological forms of adaptation through its non-genetic basis. The essence of culture can be found in the surpassing of a purely biological type of activity organization - in a human's ability to transform the world using artefacts made by standardized technology based on a predetermined hypothetical scheme and learned behavior patterns.

Culture represents an universal technology of humankind and of basic attributes by which the Homo genus differs from other animals. The specifically human capability to pass down artefacts, cultural technologies and findings ensures continuity of culture and allows for the uninterrupted accumulation of human knowledge. From this perspective, culture works as humanity's non-genetic collective memory that appears in the form of cultural heritage. This consists of a super-organic layer of reality subject to laws that are different than those of the world of inorganic and organic nature.

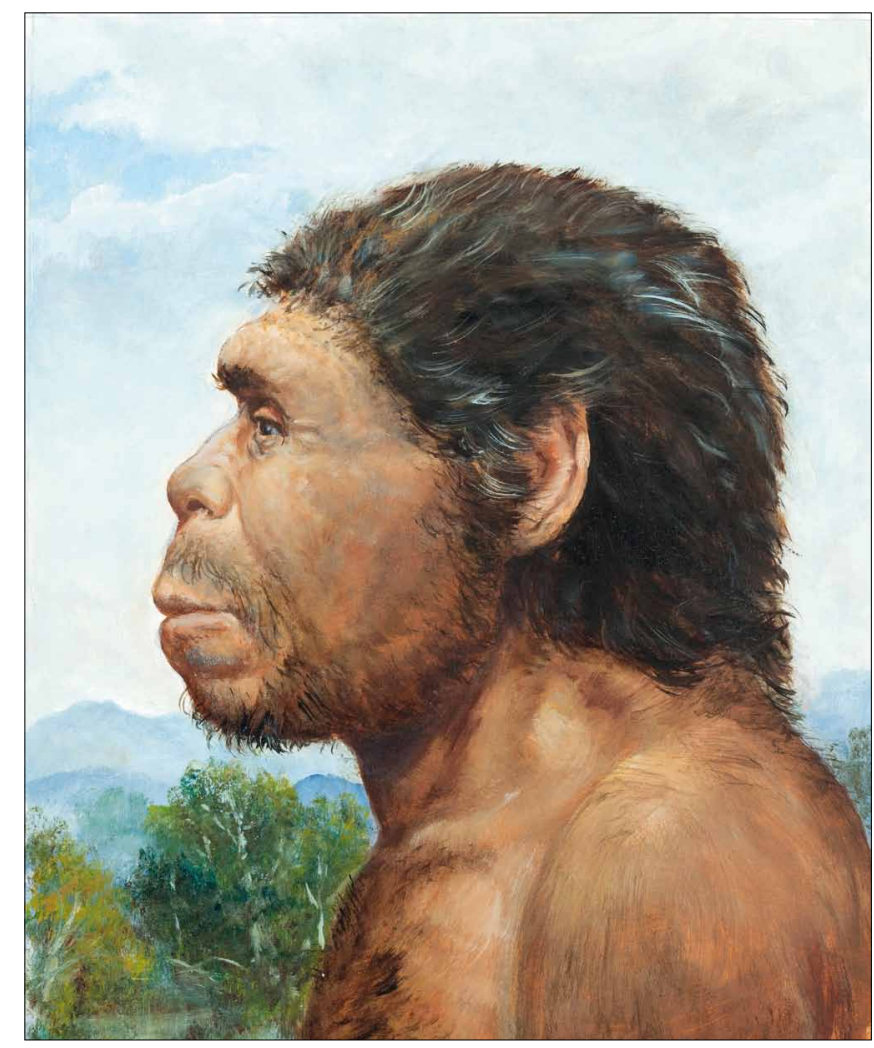

Fig. 1. Homo heidelbergensis. (c) Petr Modlitba.

\section{THE EVOLUTIONARY ODYSSEY OF THE HUMAN SPECIES}

The evolutionary odyssey of the human race is just as long and convoluted as the effort of scientists who reconstruct the course of anthropogenesis. An increasing number of fossil remains of our ancestors meant that the genealogical tree showing the hypothetical course of the evolution of mankind is continually refined and complemented. Over the past decade paleoanthropology has turned into a comprehensive, interdisciplinary-ranging scientific discipline that describes and interprets the evolution of mankind programmatically, using an increasingly wider range of human sciences (Begun 2013; Cela-Conde - Ayala 2007; Henke - Tattersall 2015; Klein 2009; Larsen 2010; Lewin 2005; Muehlenbein 2015; Soukup 2015; Svoboda 2014; Tattersall 2012; Tattersall - Schwartz 2001; Vančata 2012; Wolpoff 1999; Wood 2011).

The fossil remains of our ancestors suggest that the process of anthropogenesis started 7-6 million years ago in Central and East Africa. Primates, who share with current chimpanzees and gorillas a common ancestry, are now referred to as Hominins. The oldest hominin species is thought to be $\mathrm{Sa}$ helanthropus tchadensis who inhabited the varied coastal ecosystem of the prehistoric lake located in today's Chad before 7-5 million years ago (Brunet - Guy - Pilbeam et al. 2002). Among the archaic hominin there were also representatives of Orrorin and Ardipithecus whose fossil remains have been found in East Africa (Haile-Selassie 2001; Senut - Pickford 
- Gommery et al. 2001; Simpson 2010, 2013; White - Suwa - Asfaw 1994).

A great influence on primate evolution has been climatic changes. The climate at the time of the transition from the Miocene to Pliocene was very dry. There was a decline of tropical forests and increasing semi-open and open ecosystems in Africa, especially those of subtropical tree cover and forest steppe. These dramatic ecological changes do not encourage biological diversity, but rather caused a reduction in the number of plant and animal species. Ecosystemic changes led to the decline of those primate species that were highly specialized in the rainforest environment. The first hominins successfully adapted to these new conditions. They used new adaptation strategies - bipedalism, which influenced the transformation of morphological structures and behaviors, and the development of the hominin brain (Harcourt-Smith - Aiello 2004; Hunt 1994, 1996; Isbell - Young 1996; Niemitz 2010; Robinson 1972; Stern - Susman 1983; Steudel 1996). The emergence of bipedalism probably related to changes from primeval forests to forests, steppes and scrub savanna (Gebo 2010). This ecological pressure forced hominin to obtain food over a fairly extensive area. The new environmental conditions, the slow walk on two legs, proved to be an energy-efficient way of overcoming great distances. Upright stance made it possible. This allowed for the collection and efficient transportation of food to a safe haven where it could be consumed (Rodman McHenry 1980). Early hominid bipedalism allowed not only for the collection of food from diffuse sources, it also contributed to the development of new methods of acquisition. With hands and erect body, hominin could reach-the fruits that grow on high, previously inaccessible thorny bushes. Walking on two legs also allowed them to visually inspect a larger territory, reducing the risk of an unexpected attack by wild beasts and facilitating the identification of potential sources of food and water. Comparison of the forms of human locomotion with that of chimpanzees demonstrate that human bipedalism is much more energy efficient than quadrupedalism (Rodman - McHenry 1980). Locomotion of archaic hominid Sahelanthropus, Orrorin and Ardipithecus was unique with specific biomotorics that allowed these hominins to combine ground bipedalism with arboreal movement. Despite the crucial importance that bipedalism had for the further evolution of the human race, one must realize that the first hominin were "human" only because of locomotion. Their skull, jaw, teeth and upper limbs continued to resemble apes.

In our opinion, the genus Ardipithecus that lived 5.8 to 4.3 million years ago in the densely forested ecosystem of East Africa played a significant role in the evolution of early hominin. Their fossil remains, found in today's Ethiopia (Middle Awash), indicated that it was about $120-130 \mathrm{~cm}$ high primates and weighed between $35-50 \mathrm{~kg}$. The brain size of Ardipithecus was about $320 \mathrm{~cm}^{3}$. In a number of dental and cranial samples features still persisted strongly reminiscent of archaic features of a chimpanzee, but the great occipital hole (foramen magnum) in comparison with apes is positioned closer to the center of the brain base. Also, the elbow joint of Ardipithe-

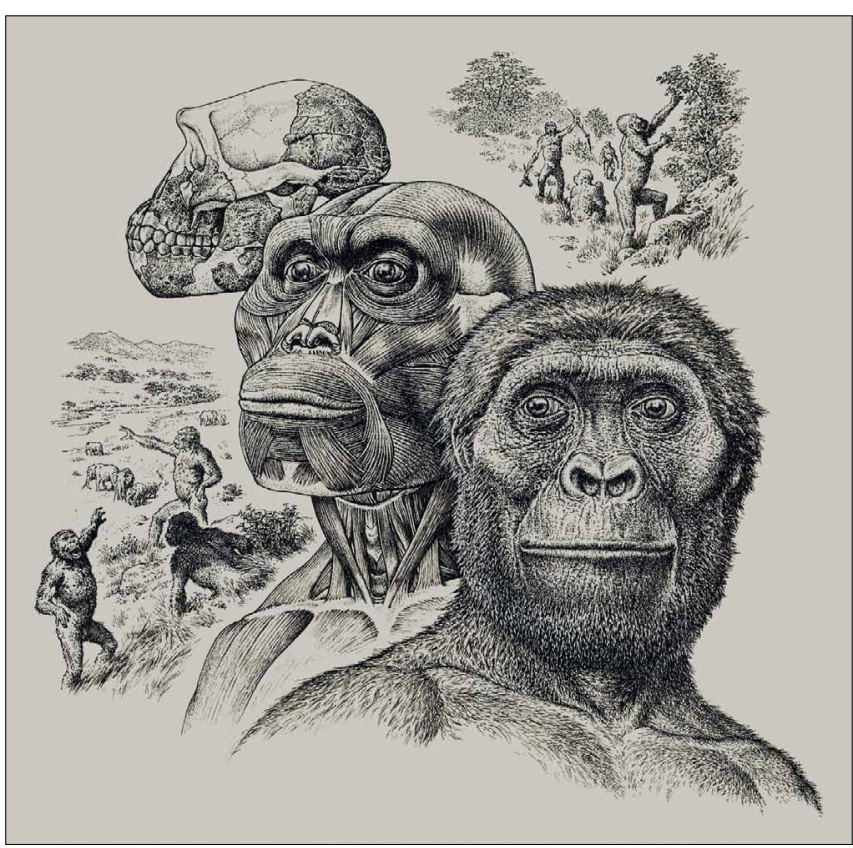

Fig. 2. Australopithecus afarensis - reconstruction of cranial and anatomical structures. (C) John Sibbick.

cus is clearly distinguished from elbow joints of apes moving through the trees. Bipedality of Ardipithecus is evidenced not only by the position of the occipital hole, but also by the structure of the trunk, the shape of the pelvis and extended lower limbs. Yet it is clear that the locomotor system of Ardipithecus featured a specific type of bipedalism, which was in many parameters different from the walking manners of anatomically modern humans (Haile-Selassie 2001; Simpson 2013; Soukup 2015: 484-492; Svoboda 2014: 191-195; Vančata 2012: 98 101; White - Suwa - Asfaw 1994).

During the Pliocene and Lower Pleistocene before 4.2 to 1.2 million years inhabited the territory of today's sub-Saharan Africa, members of the genus Australopithecus. It is likely that these bipedal hominins played a decisive role in the emergence of the genus Homo. In the course of evolution, under the influence of climate and ecosystem changes, some members of certain species of australopithecines gradually became vegetarian. These were robust because their specific morphological traits are associated with the consumption of solid and fibrous plant foods. Some paleoanthropologists classified them in the genus Paranthropus (Wood - Schroer 2013). Before the 1.4 to 1.2 million years, these hominin exhausted their potential for adaptation and died out.

By contrast, the morphologically and ecologically food-flexible gracile archaic Australopithecus gradually transformed into an evolutionarily advanced species. Probably from this line there formed the first representatives of the genus Homo. Although Australopithecus exhibit a distinctive mixture of primate and human morphological characters, from an evolutionary point of view there is a clear shift from early hominin forms of the genus Homo. This evolutionary trend can be seen in changes in volume and shape of the skull, teeth transforma- 
tions, construction of the hull, pelvic shape differentiation of function of the hand, leg reconstruction and development of bipedalism. Evolutionarily advanced Australopithecus probably were like contemporary apes in their ability to use natural objects as tools. The recent discovery of 3.3 million-year-old stone tools called lomekwian found on the western shore of Lake Turkana in Kenya suggests that some of the australopithecines, possibly members of the species Australopithecus afarensis, managed to produce a primitive industry. Australopithecines evolutionary status as potential evolutionary ancestors of the human race is still the subject of debate (Begun 2013; Henke - Tattersall 2015; Klein 2009; Larsen 2010; Muehlenbein 2015; Soukup 2015; Svoboda 2014; Vančata 2012; Wolpoff 1999; Wood 2011, 2013).

Currently, the already classic evolutionary model favors the early ancestor of the genus Homo species Australopithecus afarensis, whose representatives inhabited eastern Africa before 3.9 to 3.1 million years (Johanson - White 1979). Discoveries of new species of Australopithecus in southern Africa and East Africa indicate that traditional evolutionary scenarios of the relationship genus Australopithecus and the genus Homo need to be reconsidered (Asaf - White - Lovejoy et al. 1999; Berger - Ruiter - Churchill et al. 2010). It has become clear that in parallel with various species of Australopithecus in East Africa there were other hominid species. Specifically, Kenyanthropus playtops that inhabited the territory of modern Kenya 3.5 million years ago and some paleoanthropologists considered it as a potential ancestor of Homo rudolfensis (Hammond - Ward 2013; Leakey - Spoor - Brown et al. 2001).

Recent discovery of a previously unknown species of hominin called Homo naledi may also bring a new perspective on the anthropogenesis (Berger - Hawks - Ruiter et al. 2015). Fossil remains were discovered in 2013 in dolomite cave Dinaledi (cave complex Rising Star) in South Africa. More than 1,550 bone fragments, originating from at least fifteen individuals, made possible to reconstruct an almost complete skeleton of hominin whose morphology resembles both members of the species Australopithecus (structure of the shoulder and pelvic bone, curvature of the fingers enable climb trees) and an early species of the genus Homo (shape skull structure thumb, wrist and palm of the hand, a long lower limbs, modern human feet). Inclusion of Homo naledi into the genealogical tree of the human race is very problematic, because it is still not identify the age of the fossil remains. But if we start from a specific mosaic of its morphological characters, then it is likely that this hominin lived before 3-2 million years ago and is located on the imaginary evolutionary continuum that connects members of the genus Australopithecus with the first representatives of the genus Homo. One cannot exclude the hypothesis that this is a much younger fossils that belonged to the archaic people who have developed parallel and independently from evolutionary line leading to anatomically modern man (Shreeve 2015).

The first members of the genus Homo cleaved from Australopithecus before 2.8 to 2.5 million years. Sometimes it is dif- ficult to distinguish between early species of the genus Homo from evolutionarily advanced Australopithecus or representatives of the aforementioned species Homo naledi. The latest major discovery documenting evolutionary divergence between the australopithecines and archaic humans is the lower jaw, with five teeth of early species of the genus Homo. The 2.8 million-year-old fragment of mandible (LD 350-1) was found in 2013 at site Ledi-Geraru in Afar (Ethiopia) and reclassified the existence of the genus Homo about 400 thousand years ago (Villmoare and Kimbel and Seyoum 2015). Nevertheless, it is possible by comparison with Australopithecus to define several basic evolutionary trends typical in the further development of the genus Homo:

1. Reduction of the facial portion of the skull, teeth and chewing muscles.

2. Increasing the size of the skull and the extent of the neocortex.

3. Development of bipedalism and anatomical structures that enable highly efficient walking and running.

4. Greater dependence on stone tools and other artifacts.

5. Prolongation of maturation.

6. Growing importance of social learning as a tool of adaptation to the external environment.

7. Learned behavioral patterns as determining culture.

About 2.7 to 2.5 million years because of glacial movement the average climate temperature fell sharply and accelerated the transformation of moist woodlands of Africa in drier, open savanna. As a result of climate change vast forests disappeared and there formed vast open spaces, overgrown grass and scattered groups of low shrubs and trees. The East African ecosystem gave rise to dominant species of birds feeding on steppe vegetation. It is likely that this ecological pressure had a significant share of differentiation of hominins into several separate lines of development. Fossil findings indicate that in one of those evolutionary lines (2.8 million years ago) were discovered the first representatives of the genus Homo. Before the 2.5 to 2.1 million years in East Africa, there lived representatives of the genus Homo rudolfensis, with characteristics of both australopithecines and early species of the genus Homo. Before 2.1 to 1.6 million years ago East Africa was inhabited by representatives of Homo habilis, the first relatively stabilized form of the genus Homo (Rightmire 2010; Schrenk 2013; Soukup 2015: 593-633; Svoboda 2014: 233-239; Vančata 2012: 137-146). In comparison with the australopithecines the face of members of Homo habilis was smaller and narrower. His weight fluctuated between 32 (women) to 52 (men) kilograms, measuring $125-157 \mathrm{~cm}$. The head of Homo habilis stretched, molars and premolars downsized, brow ridges were considerably reduced and brain capacity increased. The sagittal crest bone disappeared, typical for robust australopithecus, and the profile line of the skull is not concave, but straight. Although the lower jaw remained robust, a salient chin dimple monkey disappeared. The dental arch became shorter and more rounded than in australopithecus.

The essential difference between the australopithecines and Homo habilis increased skull capacity, which on average 
ranged from 600 to $800 \mathrm{~cm}^{3}$. This is only half the average content of the skull of contemporary man, yet nearly twice that of Australopithecus. Members of the genus Homo 2.6-2.5 million years ago began to produce a primitive stone industry, the Oldowan culture. The deliberate and technologically standardized production of stone tools can be considered the humankind's oldest cultural heritage. This consisted of both heavy tools (chisels, hammerstone and proto-bifaces) and light tools (sidescrapers, scrapers, splitters, etc.) While heavy tools were created from lava or quartzite, light tools were made from flint and siliceous rocks. A typical artefact representing the Oldowan culture is the pebble chopper - a simple pebble tool with the edge made of lava or quartzite. The production of the first stone tools can be considered as qualitative leap in human evolution - the genesis of culture as a supra-biological means of human adaptation to the external environment. Primitive chopper and 2-3 cm-long, extremely sharp flakes from the eastern African sites of Gona and Turkana are thought to be the oldest tools ever. Traces indicating activities such as cutting meat, grass, plants and wood can be identified through the microscopic analysis of 2.6-2.5 million-yearsold tools. The production of choppers was diffuse mainly in the early phases of Homo development, though we also come across it in Upper Paleolithic cultures (Adams - Blades 2009; Soukup 2015: 630-633; Svoboda 2014: 244).

1.9-1.8 million years ago in East Africa emerged evolutionarily advanced representative of the human race. It was Homo ergaster, whose representatives differed from Homo habilis as denoted by taller stature, higher content of the skull (600-950 $\mathrm{cm}^{3}$ ) and better psychomotoric skills (Soukup 2015: 636-653; Svoboda 2014: 249-254; Vančata 2012: 152-160; Walker Leakey 1993). Homo ergaster spread before 1.9 to 1.3 million years ago from Africa and successfully colonized vast areas of Eurasia. During this migration there originated in Asia a new species - Homo erectus inhabited before 1.8 to 0.4 million years in East and Southeast Asia. Asian Homo erectus differed from African Homo ergaster, with thicker bones, the typical roof-shaped upper part of the skull (sagittal keel), significantly longer skull cranked poll, rounded mounds and zygomatic higher cranial capacity $\left(700-1225 \mathrm{~cm}^{3}\right)$. Its relatively robust $170-180 \mathrm{~cm}$ stature was perfectly straight, and walking and running was probably not much different from the locomotion of our contemporaries. Hominins remains showing morphological characteristics typical of Homo erectus have been found mainly in Southeast and East Asia in Java and in China (Antón 2013; Boaz - Ciochon 2004; Lanpo - Weiwen 1990; Soukup 2015: 653-694; Svoboda 2014:257-274).

During the evolution of the species Homo ergaster and Homo erectus Acheulean culture replaced the Oldowan culture. Manufactured stone tools produced before 1.5 million years ago with Acheulean technologies were found, for example in the East African area Konso-Gardula in Ethiopia. Acheulean culture over the next million years spread from Africa to the west and to south Asia and Western Europe, which prevailed from 0.7 to 0.5 million years ago. In Southeast Asia, China and South Korea, Acheulean industry occurs only sporadically.
A typical representative of Acheulean culture is the hand axe - a simple, flat retouched stone tool of teardrop shape. The hand axe was a product of new technology, and it consists of two-sided stone coring with stone wand although in later periods it was wooden. The product was usually composed of a coarser, sometimes rough base, serving as a handle, and two lateral sides with machined edges that converged in a sharp peak. The geometry of the tool changed as did the surface techniques. Besides the hand axe, people made other types of tools, typical for the species Homo erectus in the territory of Southeast Asian nations (Adams - Blades 2009; Andrefsky 2008). Material-based culture in the older Palaeolithic period, however, did not form only a stone industry, but also woodwinds and simple shelters. It is likely that human adaptation to the external environment was the use of fire. At the level of social behavior one can assume this promoted reciprocity, the growing significance of learning in childhood, and the development of learned behavior patterns.

An evolutionary shift from Homo ergaster to the early forms of Homo sapiens is linked with the emergence of archaic Homo sapiens, which spread before 700 000-200 000 years ago in Africa and Eurasia. The classification of archaic Homo sapiens formerly included a wide spectrum of advanced hominin whose anatomy showed a distinctive combination of erectoid and sapient characters. Currently, instead of the traditional name archaic Homo sapiens the name Homo heidelbergensis is increasingly used (Hublin 2013; Soukup 2015: 710-741; Svoboda 2014: 291-294; Vančata 2012: 153-172).

The evolution of the species Homo heidelbergensis, is indicated in an increasing mental potential level of communication skills, language skills development and further improvement of technological skills in the production of stone tools.

Within Acheulean technology, processing of tools became more refined and sophisticated, making use of retouching by soft impacts. Before the 350-300 thousand years ago there appears Levallois technique, characterized by the production of thin flakes of prefabricated flat stone core (Svoboda 2014: 301-303). Besides stone industries, simple hunting shelters, primitive leather garments and the use of fire were part of material culture, through which Homo heidelbergensis adapted to the external environment. They obviously had successfully combined the collection of plant foods and an increasing efficiency hunting animals. Much evidence also suggests that during the evolution of the species Homo heidelbergensis in the period before 500 to 300 thousand years ago, an early form of human language emerged. According to current knowledge in paleoanthropology, Homo heidelbergensis played a crucial role in the final stages of evolution of the genus Homo. It is probable that this is a common ancestor of Homo neanderthalensis and Homo sapiens. Hominin discoveries of fossils and paleogenetic research suggest that in the circuit of European representatives of the species Homo heidelbergensis originated the first Neanderthals, while the African line of Homo heidelbergensis played a crucial role in the birth of anatomically modern humans over 200 thousand years ago. If this hypothesis is correct, then Homo heidelbergensis represents an 
important evolutionary crossroads of anthropogenesis. From the circle of African Homo heidelbergensis before 200-140 thousand years ago in sub-Saharan Africa derived the first Homo sapiens. Anatomically modern humans followed over the centuries in several migration waves from Africa to penetrate large areas of the Old and New World, Australia and Oceania, and replaced all the different kinds of hominin. Their expansion to Europe, which began over 40 years ago, included confrontation with their evolutionary cousins - $\mathrm{Ne}$ anderthals, who they definitively and successfully pushed out of the European territory and neighboring areas of western Asia 26 thousand years ago.

Genealogically related to descendants of Homo heidelbergensis - the African origin of anatomically modern humans and Neanderthals of Europe ended in victory for the species Homo sapiens, that, thanks to the cognitive revolution, creativity and ever-increasing social and material culture technology became ruler of the planet. Revealing the key role played by Homo heidelbergensis during anthropogenesis was not easy for the paleoanthropologists. It was necessary to take three steps to ensure that the place of Homo heidelbergensis in the genealogy of the human race really belongs to him: (1) obtain a representative sample of hominin fossil remains and demonstrate that it is an autonomous kind of hominin; (2) revise the evolutionary status and the territorial distribution of the species Homo erectus; and (3) adopt a new taxonomic approach to fossil findings, which has traditionally been known as archaic Homo sapiens. One of the sources of the "paleoanthropological collision" of prehistoric people in Europe was in the second half of the 19th century that witnessed the discovery of the bones of prehistoric Neanderthals and anatomically modern humans, known as Cro-Magnons, but in the period before the 700-200 thousand years ago discoveries of fossil remains of our ancestors were missing. However, archaeologists found more Acheulean stone industries that represented perfect, bilaterally machined knockdown wedges of different shapes. The question scientists asked was simple: "Who were the creators of these artifacts?" The problem was that the stone tools archaeologists unearthed in the context of the fossil record of Neanderthals and Cro-Magnons, were more sophisticated and more technologically advanced than the Acheulean culture "Hand Axe". In the first half of the 20th century, discoveries of fossil remains of australopithecines in Africa and Homo erectus in the territory of Java and China began to fill in these findings on the paleoanthropological map. This gave birth to the idea of an evolutionary continuum from the head of the gracilis australopithecines through members of the species Homo erectus to Neanderthals and anatomically modern humans. During the 20th century Homo erectus acquired status as ancestor of Homo sapiens and creator of Acheulean culture that was found both in Europe and in large areas of Africa and western Asia. The hypothesis that members of the species Homo erectus also inhabited what is today's Europe found support in 1907 by the discovery of a massive lower jaw in the sand near the village of Mauer lying southeast of Heidelberg in Germany (Schoetensack 1908). The analysis of the layers in which the Mauer mandible was found helped to assess its age between 700 and 500 thousand years. In 1908 it acquired the status of a new hominid species Homo heidelbergensis; in the 20th century an opinion that this is a European subspecies of Homo erectus prevailed.

The Mauer prehistoric man was for many years presented as evidence of the taxon Homo erectus heidelbergensis. The tendency to classify hominid fossils from the period 700-200 thousand years ago as a subspecies of Homo erectus reflected the classification of findings in Africa and Asia. To paleoanthropological taxonomies were gradually added regional subspecies: Homo erectus erectus (1892), Homo erectus pekinensis (1927), Homo erectus modjokertensis (1936), Homo erectus mauritanicus (1954), Homo erectus lantianensis (1964), Homo erectus olduvaiensis (1968). This period taxonomic discourse included a discovery of the fossil remains of a hominin, which entered the pages of scientific publications under the name Homo erectus paleohungaricus (Thoma 1966); while the broad general public knows this unique hominin under the name Samuel. The discovery of Samuel, began a process of reassessing hominin fossil finds from the 700 to 200 thousand years ago and this challenged the presence of members of the species Homo erectus in the territory of prehistoric Europe. Since finding Samuel, scientists made a series of fossil discoveries that showed a unique mosaic of active hunting, Neanderthal and sapient features.

The specific morphology of findings made in the territory of France (Cauna del'Arago, Montmaurin, La Chaise, Fontéchevade, La Davidson, Biache), Italy (Ceprano, Altamura, Visogliano), Greece (Petralona, Apidima), Germany (Bilzingsleben), England (Boxgrove, Swanscombe), Spain (Atapuerca, Cova Negra) and Serbia (Mala Blanica) eventually led to a reassessment of the traditional hypothesis that these are remains of Homo erectus. Paleoanthropologists initially tended to involve a broad spectrum of hominid finds from the front 700-200 thousand years ago under the "archaic Homo sapiens." It became clear that they are representatives of the relatively autonomous hominin species Homo heidelbergensis. That is why we consider it important to mention an important milestone on the long journey to the constitution of the taxon Homo heidelbergensis: the discovery of Samuel and accredit him on the occasion of his 50th anniversary with the evolutionary status he certainly deserves in light of new discoveries.

\section{HOMO ERECTUS PALEOHUNGARICUS}

The "paleoanthropological crisis", launched by the Samuel discovery is connected with a small Hungarian village, Vértesszőlös, located in the northern part of the Pannonian Plain in the foothills of the Gerecse Mountains in the district of Tatabánya. Through the village flows the $51 \mathrm{~km}$-long river Által-ér, and is excavated in four to five travertine terraces. Fixed travertine sediments precipitated from the mineral springs in this area consist mainly of pure calcite $(94,52$ to 98 , $88 \%)$. Travertine terraces are exceptionally intact here and 


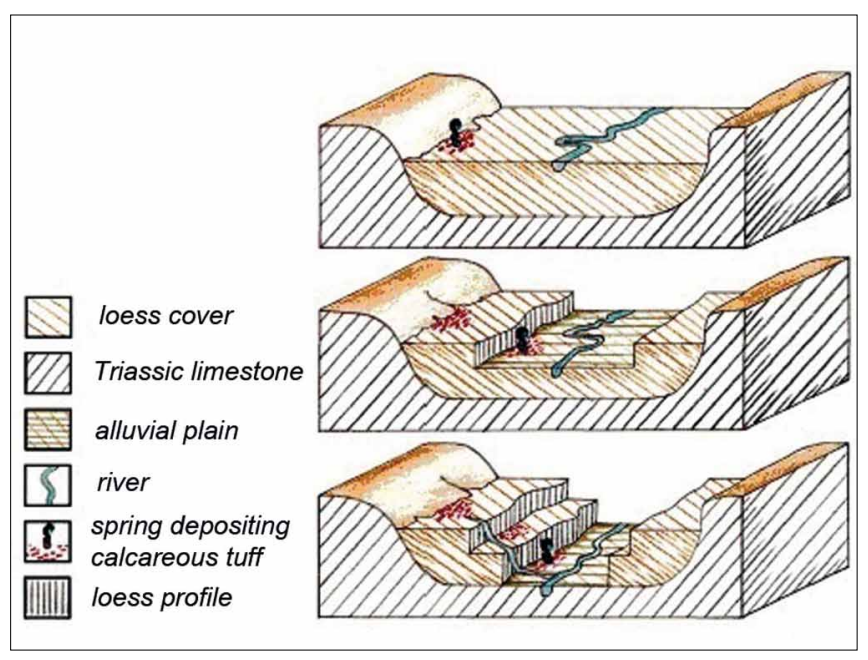

Fig. 3. Model formation of river terraces. (c) Zdenka Mechurová.

well-preserved, attributed to the calcium tufa that played an important role in the preservation of prehistoric organic and inorganic sediments (Dobosi, 1999: 7-9).

Quaternary local traventien is also a valuable source of paleohydrologic and paleoclimatic informations (Kele et al. 2006). For paleoanthropologists who deal with the reconstruction of human evolution the most important is that IV - V. travertine terrace of the river Által-ér remains were discovered in two settlements of prehistoric hunters who probably inhabited this area before the 400-200 thousand years ago (Kele 2009: 95; Svoboda 2014: 283). Geomorphological, paleontological and paleobotanical findings suggest that people inhabited this area during the second ice age (Mindel glaciation). At the time of the first settlement here the climate was milder and warmer and many indications suggest that in January the average temperature did not fall below minus $3^{\circ} \mathrm{C}$.

Since 1900 Vértesszőlös has been of interest for scientists. Paleontologists and geologists found fossil remains of prehistoric fauna. On the outskirts of the village is a quarry where animal bones were discovered that dated hundreds of thousands of years old (Dobosi, 2003: 78). This was contested, in 1962, by the Hungarian geologist Márton Pécsi (1923-2003) and his students who conducted a survey stratigraphic layers of travertine. Based on their research the Hungarian Academy of Sciences and the Hungarian National Museum in Vértesszőlös launched systematic archaeological excavations. Subsequent research between 1963 and 1968 was led by the Hungarian archaeologist, paleontologist and historian László Vértes (1914-1968). Vértes, who worked at the Hungarian National Museum where he was responsible mainly for prehistoric collections, his experience applied during the excavations in Vértesszőlős acquired during his research of prehistoric sites in the Hungarian city of Tata.

The Hungarian paleontologist and geologist András Tasnádi Kubacska (1902-1977), helped Vértes with the analysis and interpretations of geological ecofacts. They uncovered several cultural layers that housed, two permanent hunting estates,

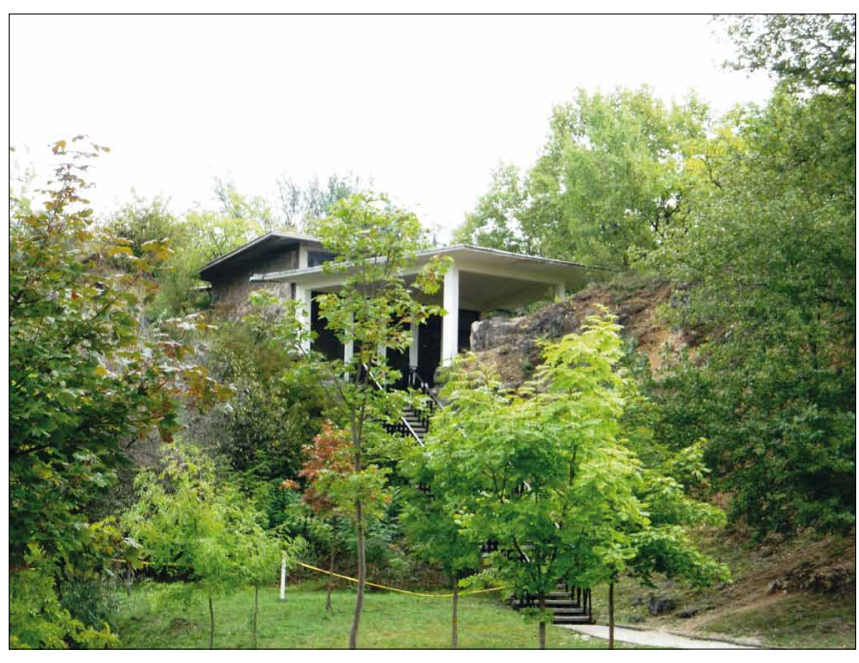

Fig. 4. Museum in Vértesszőlős. @ Zdenka Mechurová.

hominin fossils, an extensive collection of prehistoric industries and a place that served for cutting of hunted animals. In hardened mud they also discovered footprints of local fauna and the imprint of a human foot. The Hungarian archaeologist Viola Dobosi (1942- ), who worked during the excavations as Vértes's assistant, was convinced that Vértesszőlös represents an exceptional and unique prehistoric archaeological site. In her opinion, this is due to the unique topographic positions within Europe (Vértesszőlős is located away from the sea), and the local findings represent the fact that the travertine structure provided numerous archaeological excavations fossils, prehistoric artifacts and the original ecofacts in stratigraphic deposit (in situ). The wealth of prehistoric flora and fauna allows for the reconstruction of the original environment and can be used to determine the age of the findings using biostratigraphic dating methods (Dobosi 2006). Individual cultural layers uncovered in Vértesszőlős, are now open to the public in the local paleoanthropologic museum - in two museum buildings erected above the site. One building protects site I. where there are traces, the second building covers site III., where they the remains of Samuel were discovered. Both sites are accessible to visitors and visible through a window. There are 4 cultural layers. In site III. there are five cultural layers. Among the most valuable finds discovered was the site of a hunting estate, and 350,000-year-old remains of fire, discovered in 1966 by István Skoflek (1934-1981). Uncovered in the loess layer was charcoal five centimeters thick and 7 meters wide. In a prehistoric fire were charred fragments of animal bones, which probably served as fuel and kept "alive" the smoldering fire. The discovery of fire from the period of middle Pleistocene played an important role in supporting the hypothesis that ancient people used fire as early as the Lower Paleolithic period. A very important part of the discovery in Vértesszőlös was a stone industry and stone fragments that served as tools for cutting. It was the chipped stone industry, usually made of quartz and quartzite cobbles or from silex. An important source of raw materials that prehis- 


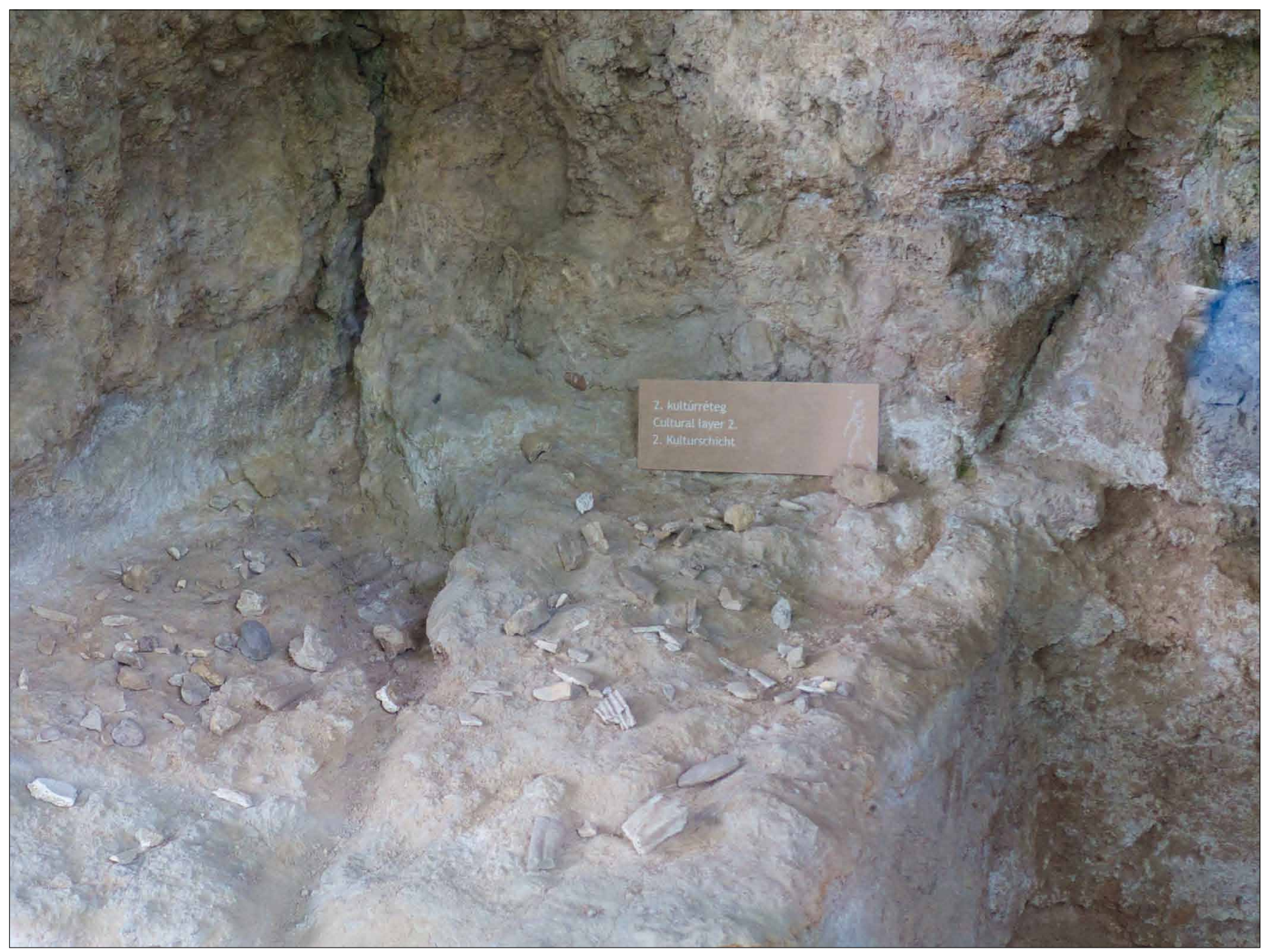

Fig. 5. Cultural layer 2. (c) Zdenka Mechurová.

toric hunters used to produce artifacts was found in silts and sediments of the river Által-ér. The creators of these industries carefully selected boulders modified by splitting. A characteristic feature of this collection of artifacts is their microlithic character (Friedrich 2005: 210). Stone tools, the mean length of 2.4 centimeters, were apparently used by prehistoric hunters in cutting and carving, leather processing of hunted animals or manufacturing of wooden artifacts such as spears or everyday objects. On instruments found in higher cultural layers is recorded a gradual growth of technological innovation. Compared with the older industry found in the lower layers, these tools vary in material and have a more careful treatment. At the site with an area of $103 \mathrm{~m}^{2}$ was discovered 8900 chipped stone tools on the base of the Vértes tried to determine some typological classes. This created a typology of standardized tools generated from local stone industries that included 50 different types of tools. This number, however, was not identical with a number of features that determined their use. A very useful part of the archaeological finds were ecofacts included in the "production waste" as contributing to the reconstruction of production techniques. In the cultural layers were also discovered 105 fragments of bone artifacts that had the tool function. These bone industry were sometimes processed in a manner similar to stone tools. Among the unique discoveries in this regard was a bone Hand Axe. Also found were parts of the bones, clearly identified as the remains of food because they bore traces, and were left the tools used for trimming meat and getting the bone marrow. The natural environment of Vértesszőlös provided prehistoric hunters and gatherers with good conditions for obtaining food. In a place that before 350 years ago was used to process the meat of hunted animals were documented two types of activities - the first related to animals by depleting the skin, the other with a filleting meat. Archaeological findings prove that prehistoric people made their living from Vértesszöllös smaller and larger herbivores and wild beasts. Fragments of animal bones, jaws and teeth suggest that the most common meat for local hominin was horse. But there were also aurochs, bison, deer, wolf and roe. Found also were bear bones but it is not clear whether these are remains of hunted animals or bones humans brought in from elsewhere. Among the rocks were many animals that apparently died naturally. 


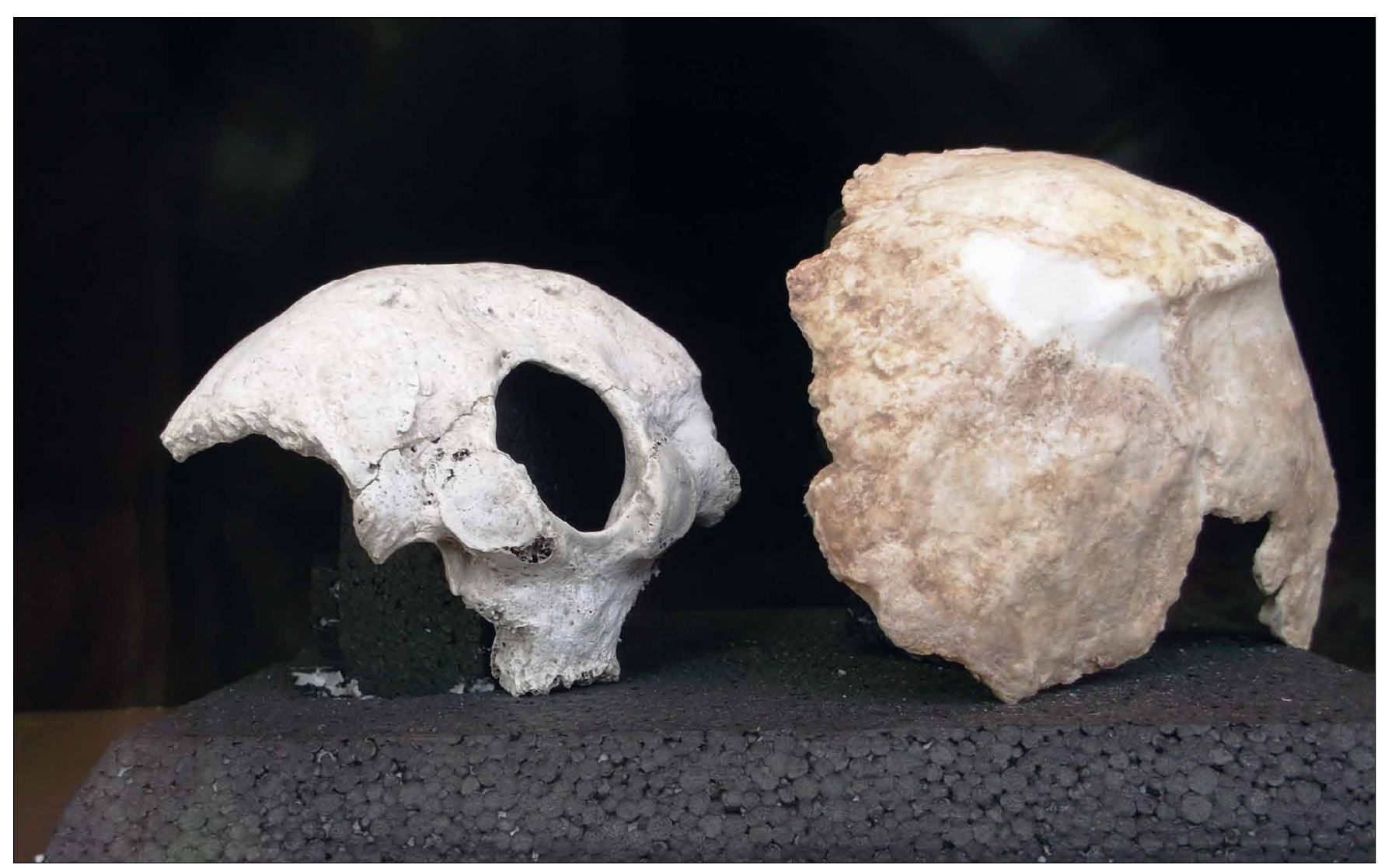

Fig. 6. Model of occipital bone of Samuel. (c) Zdenka Mechurová.

An extraordinary discovery in Vértesszőlős occurred in 1965, when slightly fossilized remains of two individuals were discovered. In the first of these, known as VSZ I., were four fragments of teeth - three milk teeth and the permanent part of the left molars of a seven year old child. Analysis of these teeth showed similarity to the teeth of members of the species Homo erectus, found in Zhoukoudian, China. The other individual (Vsz II) who caused a sensation in the world of paleoanthropology was Samuel.

His remains were discovered on $21^{\text {st }}$ of August, 1965 in a travertine layer at a distance of about 8 meters from dental fragments of individual from site VSZ I. These findings were estimated at 350,000 years old, while the use of resonance method determined an age of $333000+/-17,000$ years. The maximum age of the layers was set at 600,000 years. Morphology found occipital bone fragment suggesting that it is an adult human. The structure of the bone is relatively thin and the top of the rear flattened. On her back is a well-developed nuchal hump, to which is attached very large neck muscles. Area, which is located below the bulge nape separates some distinct furrow. Based on the size of the occipital bone was Samuel's skull, its cranial capacity estimated at $1,300 \mathrm{~cm} 3$. The distortions that are visible on the skull bones, was caused by storage in travertine layer. On the occipital bone are also traces, about which Vértes theorized, that he said arose during the ritual removal of the brain and supposedly testify to cannibalism.
Today most scientists reject this hypothesis. Opinions on the evolutionary status of Samuel's remains are controversial. The fact that the bones were incomplete and severely eroded is one reason, and also because at the time there were no comparable hominin fossil remains. Because Vértes had not the knowledge and experience with cranial fragments, he requested assistance from prominent Hungarian anthropologist Andor Thoma (1928-2003), an expert in evolutionary anthropology. Thoma hesitated over a distinct classification of hominid remains found in Vértesszőlős. Like other paleoanthropologists, who tried to include Samuel in an evolutionary continuum, he hesitated whether they were an European representative of the species Homo erectus or an early Homo sapiens. These doubts are reflected in the label, that Thoma used as a generic term for fossils found - Homo erectus (seu sapiens) paleohungaricus. Already this label is encoded but "peripeteia" connected with Samuel's morphology, which is the problem, whether it is a species of the Homo erectus or some early form of Homo sapiens. Vértes, in his book Stone Trail: The story of the Prehistoric Man from Vértesszőlös (1969), inclined to the view that Samuel is representative of the species Homo erectus (Vértes 1969: 214). A similar conclusion was reached by South African paleoanthropologist Phillip Vallentine Tobias (1925-2012) studying the skull fragments who also found no reason for the hypothesis that Samuel should be considered as a member of the species Homo sapiens. Tobias differed from the Hungarian 
archaeologists with his view of the volume of the Samuel skull. Tobias differed from Hungarian archaeologists with his opinion on the volume of the Samuel skull. He believed that the volume of the skull is smaller than Andor Thoma estimated. At present the majority of palaeoanthropologists believed Samuel brain size is slightly larger than the lower limit of normal variability in the brain of modern man. The fact that Samuel had a relatively large brain is reflected in the overall construction and shape of skull and facial bone. Samuel fossil remains, as well as the stone industry found in Vértesszőlős, immediately attracted the interest of leading world palaeoanthropologists. One of the first major international scientists who responded to the discoveries made in Vértesszölös, was the American anthropologist Francis Clark Howell (1925-2007), who on studying Samuel pointed this out in his book Prehistoric man (1965). Howell, who personally visited Vértesszőlős, traveled to Tanzania to discuss his findings with the famous British paleoanthropologists Louis and Mary Leakey (Vértes 1969: 142). Among the famous visitors of Vértesszőlős, were also British physical anthropologist Kenneth Page Oakley, a German paleontologist Helmuth Zapfe and paleoanthropologist Gustav Heinrich Ralph Koeningswald. Not all palaeoanthropologists agreed with the conclusions of Andor Thoma after examining the fossil remains of Samuel. For example, an American paleoanthropologist Milfford Wolpoff (1942), who examined the fossils in 1977, drew attention to the fact that the skull fragment from Vértesszollös is a unique specimen of the second ice age (Mindel). In his opinion, it is difficult to draw conclusive generalizations from a fragment sample. It cannot represent the complex morphology of the studied population. Meaning sample according to him, but consists in the knowledge of evolutionary developmental lines linking the species Homo erectus and Homo sapiens. The fact that at the time of the discovery it was a unique European hominin sample from the period 400 to 200 thousand years ago could have been the reason why its importance was overestimated.

Finally Wolpoff highlighted the incompleteness of the sample and its eroded state (Wolpoff 1977: 357). In 1971 Andor Thoma responded to Wolpoff's critical remarks, who published a study in the Nature journal, in which he admits that the scientific community is divided into two groups over the interpretation of Samuel fossils.

Some experts have theorized that Samuel is Homo erectus, others look to from a relatively large volume domed skull, consider it to be the remains of Homo sapiens. There were also palaeoanthropologists who paid increased attention to the morphological characteristics that suggested Samuel's evolutionary kinship to Neanderthals. Specifically, there is the occipital morphological structure reminiscent of the characteristic bulge in the occipital region (occipital bun) with $\mathrm{Ne}$ anderthals. A new approach to the interpretation of Samuel fossils from this point of view, for example, was the British paleoanthropologist Christopher B. Stringer (1947) who called Samuel one of the last "preneanderthals",that represents the European representative but autonomous hominin Homo heidelbergensis (Wolpoff 1999: 644-645).

\section{DISCUSSION}

The key to uncovering who was Homo erectus seu paleohungaricus sapiens, were fossil discoveries made in the second half of the 20th century in Europe. Comparative space for examining the morphology of Samuel's occipital bone was provided by, e.g., a hominin skull known as the Petralona 1, discovered in 1960 by speleologists in a cave near the village Petralona south of Thessaloniki in the Greek province of Chalkidiki. Approximately 350-200 thousand years old skull, described by P. Kokkoros and A. Kanellis, presents like the skull fragment from Vértesszőlős unique mosaic presapient and sapient morphological characters. A big and rugged face with its massive arches reminds one of Neanderthals, while the occipital wall is shaped similarly to Samuel. Among the distinctive features of Petralona 1 is a very strong skull and low-arched, broad braincase which volume was about 1200 cm3 (Kokkoros - Kanellis 1960; Svoboda 2014: 290). At the time of discovery Petralona 1 belonged together with a skull fragment from Vértesszőlös to rare fossil remains of presapient forms of the prehistoric man that inhabited Europe in the period in the period 700-200 thousand years ago.

In order to answer the question of who actually are these prehistoric people it was necessary to add to the collection of fossil remains. The place the next hominin fossils, were included among the findings known as archaic Homo sapiens, came from Cauna de l'Arago at Tautavel in the French Pyrenees. Here in limestone caves above the river Verdouble since 1964 conducted paleoanthropological excavations and in middle pleistocene layers found several dozen human fossils. So far, the most important finding from this area is partially preserved skull (Arago XXI), whose age is estimated at 450-300 thousand years. There were also fragments of the pelvic bones and a wide hip bone. A skull, for its size and robust build of the face attributed to a male, was discovered and described in 1971 by French archaeologist and paleoanthropologist Henry de Lumley (Lumley 1979). From an extensively damaged skull was preserved the entire face, parietal bone, and five stools. The typical morphological features include protruding brow ridges distinctly separate, large rectangular eyepiece and a broad flattened head, which turns into a narrowed skull (postorbital constriction). Bones of the skull on the sides accentuate the angular ridge that its shape resembles the morphology of Homo erectus. Unlike members of the species Homo erectus a skull from Arago lacks sagittal crest, has broader frontal bone and bigger brain volume (around 1166 $\mathrm{cm} 3$ ). It is again an example of a mosaic anatomical structure displaying an evolutionary shift from archaic features towards a more advanced Neanderthal morphological pattern. A very important location, which significantly contributed to the understanding of the evolutionary status of the European archaic Homo sapiens, is a Spanish Atapuerca cave complex, specifically the cave Sima de los Huesos, considered the largest European hominin site of the Middle Pleistocene period. Speleologists discovered this cave in 1976 while surveying the karst cave system. It was a relatively small storage room with 
a low ceiling, accessible $14 \mathrm{~m}$ deep shaft. The fill cave consisted of clay, marl, sand and bat guano. Very difficult research coupled with the removal of tons of sediment lasted for six long years. Palaeoanthropologists in a small, cold and damp cavern were working in very difficult conditions supported on wooden boards. The confined space allowed excavation by no more than five people. They carefully removed the wet clay and found hominin brittle bones and in backpacks transported them out of the cave. In the Sima de los Huesos were discovered fossil remains of at least $32 \mathrm{men}$, women and children jumbled and without any anatomic relationships, together with the bones of cave bears and other carnivores. Paleoanthropologists noted a relatively low age composition of the hominin group. Juan Luis Arsuga found that only three individuals lived for more than thirty years. Most of the fossils consists of fragments of skulls and teeth. Breakthrough research occurred in 1992 when the skull identified as SH 4 and SH 5 was discovered. Skull SH 4 has a special place among the findings from the Middle Pleistocene, not only because of the high content of the skull $(1390 \mathrm{~cm} 3)$, but also the fact that it was the remains of an individual who has been deaf since childhood, and yet, thanks to the altruistic reciprocity of members of the group managed to survive. During 1992 and 1993, it was discovered a well-preserved skull of a complete SH 5.5 Relatively small, round skull has a small capacity $(1125 \mathrm{~cm} 3)$, wide voluminous face, broad nose area and significantly protruding face. Some characteristic brow ridges, a large nose and a hole horizontal lateral portion of the occipital suture, already anticipate the Neanderthal morphological pattern. In 1994 paleoanthropologists discovered a nearly complete postcranial skeleton of man. To the skull SH 5 was added a complete pelvis, including the bones of the upper and lower extremities and trunk. With this, we know that archaic Homo sapiens who lived in Atapuerca in front 550-300 thousand years ago, had a fairly robust physique. Its height varied around $180 \mathrm{~cm}$, and it weighed 70 to $90 \mathrm{~kg}$. The way bones were stored and the absence of stone tools indicates that the remains in the cave were not dragged in by carnivorous beasts, but bytthe other members. Some palaeoanthropologists are therefore convinced that it is a proof of intentional burials. Cuts on top of some skulls and long bones also indicate the existence of cannibalism (Arsuaga - Martinez - Gracia 1993). Another important site, with evidence of the spread of archaic Homo sapiens in Europe, is the gravel pit at Boxgrove in southern England. In 1993, in layers of sand, clay and debris dating back over 500 years ago, were found shinbone, two front teeth and a large number of stone tools acheulean type (Roberts Stringer - Parfitt 1994). Robust and relatively long tibia suggest that it was a very strong, about $182 \mathrm{~cm}$ tall individual. The ecosystem where people lived at Boxgrove, formed muddy environments with little overgrown vegetation and inhabited by rhinos, bears, deer and beavers. Prehistoric people whose morphology and way of life reminded one of Samuel inhabited the settlement near the lake at Bilzingsleben in Germany. Since 1972, systematic research by the German archeologist and paleontologist Dietrich Mania (1938), in sandy sediments in the bedrock of solid travertine discovered hominid remains from younger holstein interglacial period (Mania 1986, 2004). These were fragments of the frontal bone, parietal bone and occipital bone. In the settlement were also discovered specific areas, which before 400-350 thousand years ago were used for housing, manufacturing tools and processing meat of hunted animals. There were three residential buildings situated next to each other in a semicircle. Their oval or circular plan area comprised from 5.7 to 8.7 square meters. Most artifacts of stone industry and the remains of hunted animals were found near the fires in front of these entrances. Middle settlements had a paved oval with an area of $60 \mathrm{~m} 2$, which probably served as a space for collective activities. A residential structure in Bilzingsleben suggests that the local community demonstrated an organized social structure and differentiation into smaller social units. In addition, there were stone industries, wooden tools and files stone tools including washers used to produce tools. An unique discovery was bones covered with petroglyphs, which created a very stylized structure. It is a proof of human creativity, which can be interpreted as a very early manifestation of artistic activity that illustrates the evolution of the human race before the 700-200 thousand years ago. Comparative analysis of skull fragments of Samuel fossil remains with other hominin elicited a new attitude to the somewhat vague label of archaic Homo sapiens. Palaeoanthropologists increasingly came to the view that before 700-200 thousand years ago there inhabited in the vast territories of Europe, Africa and Asia hominid members of a species that was the ancestor of both Neanderthals and anatomically modern humans. This kind of came to a genealogical map of the evolution of mankind under the name Homo heidelbergensis.

Reconstruction of the members of the species Homo heidelbergensis can be done mainly based on fossil remains of this form of human discovered on the territory of today's Germany (Mauer, Steinheim, Bilzingsleben), France (Arago), Greece (Petralona), Spain (Atapuerca), Great Britain (Boxgrove, Swanscombe ), Ethiopia (Bodo D’Aro), Tanzania (Ndutu), Zambia (Kabwe), Narmada (India), Che-Hsien, Ma-pa, Ta-li, Tching-chun (China), Ngandong (Java).

Homo heidelbergensis had a fairly robust physique, strong bones and strong muscles. Based on the postcranial skeleton (SH 5 - Elvis) found in Spanish Sima de los Huesos one assumes that Homo heidelbergensis reached the height of 175$190 \mathrm{~cm}$ and weighed $80-90 \mathrm{~kg}$. The proportion and length of the upper and lower extremities, as well as the shape of the pelvis is very similar to the morphology of anatomically modern humans. Bones are more robust and the pelvic entrance is narrower than that of modern people. In comparison with the species Homo ergaster and Homo erectus occurred gracial facial skeleton, rounding occipital region of the skull and cranial volume expansion (1100-1300 cm3). Some of the skulls of Homo heidelbergensis suggest that a brain of this kind reached its lower limit size variability of anatomically modern man. Bigger is also Broca's speech center. About a 400-300 thousand years ago by members of the species Homo heidelbergensis appears with an identical curvature (bulging) of the cranial base 
as modern man. This morphological structure refers to the low position of the larynx and the presence of laryngeal resonance space necessary for the creation of articulate speech. In the construction of the skull of Homo heidelbergensis there are still archaic features reminiscent of an evolutionary ancestor. These include massive superorbital torus, which is divided into two thick brow ridges. Other features include a sturdilybuilt skull, a large face with a relatively steep profile lines and a massive jaw. Generally, the morphology of the species Homo heidelbergensis is a distinctive mosaic of archaic presapient and sapient progressive and evolutionary traits. The origin and evolution of the species Homo heidelbergensis is probably an example in which the evolutionarily advanced species directly deriving the development of their predecessors. That is why the species Homo heidelbergensis may include a wide spectrum of morphologically diverse populations of hominin that 700 to 200 thousand years ago inhabited the vast areas of the Old World. Their evolutionary successors, who before the 200-100 thousand years ago independently differentiated into two distinct evolutionary lineages represented African anatomically modern humans and Neanderthal Europe, that eventually awaited their fateful meeting, from which emerged the only winner - Homo sapiens.

To correctly determine the evolutionary status of 350,000 year old fragment of occipital bone found in Hungarian Vértesszőlös, it is necessary to compare and analyze the finding and put it in the broader context of evolution of humankind in the period before 500 to 200 thousand years ago. Typical morphological characters which Samuel has common with other fossil findings included into the taxon Homo heidelbergensis, are relatively thin and flattened bone structure and well-developed nuchal hump, which is clamped to a very large neck muscles. In our opinion, the members of the species Homo heidelbergensis we can describe as evolutionary ancestors of both the Neanderthals and anatomically modern humans too. The evolutionary relationship of Samuel to younger Neanderthals is especially witnessed by the occipital morphological structure, its shape reminiscent of the characteristic bulge in the occipital bun of Neanderthals. The morphologically closely relation of species Homo heidelbergensis and Homo sapiens is indicated by the skull capacity of Samuel (about $1300 \mathrm{~cm} \mathrm{3),} \mathrm{which} \mathrm{is} \mathrm{slightly} \mathrm{larger} \mathrm{than} \mathrm{the} \mathrm{lower} \mathrm{limit}$ of the normal variability of human brain of modern humans. Although anatomically modern humans, were appearing before 200-140 thousand years ago in the sub-Saharan Africa, the morphology of the cranial structure of the European representatives of the species Homo heidelbergensis well illustrates the general trend of expansion of the brain during the evolution of hominids in the genus Homo. The fact that Samuel had a relatively large brain, had to be reflected in the overall construction and shape of the skull and facial skeleton profiling. Reflections and speculations on the subject of face of Samuel considerably limit the fact that the bone was found incomplete and heavily eroded. To create a general idea about the morphology of Samuel skull, it is useful to make a comparison with analogous discoveries of fossil remains of Eu- ropean members of the species Homo heidelbergensis. From this point of view especially significant is the finding of 350 to 200,000 years old skull hominin called Petralona 1, whose robust construction of facial skeleton is similar to the Neanderthals while the occipital part is shaped similarly to the Samuel. The inspiration for the reconstruction of the missing parts of Samuel skull may be the remains of the skull Arago XXI found in Caune de l'Arago at Tautavelu in the French Pyrenees or the well-preserved small skull SH 5 found in the Spanish site Atapuerca in the cave Sima de los Huesos. These fossil remains also show morphological characteristics typical of the species Homo heidelbergensis. Based on comparative analysis of Samuel occipital bone with similar European findings of skulls, we can tell that the fossil remains of Homo erectus paleohungaricus, must be reclassified. That is not a member of the species Homo erectus, but the European representative of the autonomous hominin Homo heidelbergensis.

\section{REFERENCES}

Adams, Brian - Blades, Broke S. Eds. (2009): Lithic Materials and Paleolithic Societies. New York: Wiley-Blackwell.

Antón, Susan C. (2013): Homo erectus and Related Taxa. In: Begun, David R. Ed.: A Companion to Paleoanthropology. Oxford: Wiley-Blackwell, 497-516.

Asaf, Berhane - White, Tim - Lovejoy, Owen et al. (1999): Australopithecus garhi: A New Species of Early Hominid from Ethiopia, Science, 284 (5414), 629-635.

Andrefsky, William Ed. (2008): Lithic Technology. Cambridge: Cambridge University Press.

Arsuaga, Juan-Luis - Martinez, Ignacio - Gracia, Ana et al. (1993): Three New Human Skulls from the Sima de Los Huesos, Middle Pleistocene Site in Sierra de Atapuerca. Nature, 362, 534- 537.

Begun, David R. Ed. (2013): A Companion to Paleoanthropology. Oxford: Wiley-Blackwell.

Berger, Lee R. - de Ruiter, Darryl J. - Churchill, Steven E. et al. (2010):. Australopithecus sediba: A New Species of Homo-like australopith from South Africa. Science, 328 (5975): 195-204.

Berger, Lee R. - Hawks, John - de Ruiter, Darryl J. et al. (2015): Homo naledi, A New Species of the Genus Homo from the Dinaledi Chamber, South Africa. eLife 4. doi:10.7554/eLife.09560. Retrieved10 September 20.

Boaz, Noel T. - Ciochon, Russell L. (2004): Dragon Bone Hill: An Ice-age Sago of Homo Erectus. New York: Oxford University Press.

Brunet, Michel - Guy, Franck - Pilbeam, David et al. (2002): A New Hominid from the Upper Miocene of Chad, Central Africa. Nature, 418, 145-151.

Conroy, Glenn C. - Pontzer, Herman (2012): Reconstructing Human Origins: A Modern Synthesis. New York: W. W. Norton.

Cela-Conde, Camilo J. - Ayala, Francisco J. (2007): Human Evolution: Trails from the Past. Oxford: Oxford University Press.

Dobosi, Viola T. (2001): Ex Proboscideis - Proboscidean Remains as Raw Material at Four Palaeolithic Sites, Hungary. In: Cavarretta, Giuseppe - Gioia, Patrizia - Mussi, Margherita - Palombo, Maria Rita Eds.: The World of Elephants International Congress, Rome: Consiglio Nazionale delle Ricerche, 429- 443.

Dobosi, Viola T. (1999): Palaeolithic Man in the Által-ér Valley. Tata: Alfadat Press Ltd.

Dobosi, Viola T. (2006): Tüzhelyek Vértesszőlősön. Archeometriai Mühely, $2006 / 3,1-7$

Dobosi, Viola T. (2008): Kódok és lyukszegélykártyák, Vértes László módszere az őskőkori leletek feldolgozására. Archeometriai Mühely, 2008/2, $1-6$.

Fridrich, Jan (2005): Ecce homo. Svět dávných lovců a sběračů. Praha: Krigl.

Haile-Selassie, Yohannes (2001): Late Miocene Hominids from the Middle Awash, Ethiopia. Nature, 412, 178-181. 
Gebo, Daniel L. (2010): Locomotor Function across Primates (Including Humans). In:

Hammond, Ashley S. - Ward, Carol V. 2013. Australopithecus and Kenyanthropus. In: Begun, David R. Ed.: A Companion to Paleoanthropology. Oxford: Wiley-Blackwell, 434-456.

Harcourt-Smith, William E. H. (2004): Fossils, Feet and the Evolution of Human Bipedal Locomotion. Journal of Anatomy, 204, 403-416.

Henke, Winfried - Tattersall, Ian Eds. (2015): Handbook of Paleoanthropology I. - III. Berlin - Heidelberg: Springer-Verlag.

Hublin, Jean-Jacques (2013): The Middle Pleistocene Record: On the Ancestry of Neandertals, Modern Humans and Others. In: Begun, David R., Ed. A Companion to Paleoanthropology, Oxford, Wiley-Blackwell, 517-537.

Hunt, Kevin D. (1994): The Evolution of Human Bipedality: Ecology and Functional Morphology. Journal of Human Evolution, 26, 183-202.

Isbell, Lynne A. - Young, Truman P. (1996): The Evolution of Human Bipedalism in Hominids and Reduced Group Size in Chimpanzees: Alternative Responses to Decreasing Resource. Journal of Human Evolution, 30(5), 389-397.

Johanson, Donald C. - White, Tim D. (1979): A Systematic Assessment of Early African Hominids, Science 202, 321-330.

Kele, Sándor (2009): Édesvizi mészkövek vizsgalata a Karpat medenceböl: Paleoklimatiológiai es szedimentiológia elemzések. Disertation work. Budapest: Magyar Tudományos Akadémia. Geokémiai Kutatóintézet.

Klein, Richard G. (2009): The Human Career: Human Biological and Cultural Origins. Chicago: University of Chicago Press.

Kokkoros, P. - Kanellis, A. (1960): Découverte d'um crane d'homme paléolithique dans peninsule Chalcidique, Anthropologie 64, 132-147.

Kretzoi, Miklós - Dobosi, Viola, T. Eds. (1990): Vértesszőlösön Site, Man and Culture. Akadémiai Kiadó: Budapest.

Kretzoi, Miklós - Vértes, László (1965): Lower Paleolithic Hominid and Pebble Industry in Hungary. Nature, 208, 5006.

Lanpo, Jia - Weiwen, Huang (1990): The Story of Peking Man. Beijing: Foreign Languages Press.

Larsen, Clark S. Ed. (2010): A Companion to Biological Anthropology. Oxford: Wiley-Blackwell, 530-544.

Lumley, Henry de (1979): L'Homme de Tautavel. Dossiers de l'Archéologie, $36,1-273$.

Leakey, Meave G. - Spoor, Fred. - Brown, Frank H. et al. (2001): New Hominid Genus from Eastern Africa Shows Diverse Middle Pliocene Lineagas. Nature, 410, 433-440

Mania, Dietrich (1986): Die Forschungsgrabung bei Bilzingsleben. Jahresschrift für Mitteldeutsche Vorgeschichte, 69, 235-255.

Mania, Dietrich - Mania, Ursula - Wolf, Dietrich-Heinrich, et al. (2004): Bilzingsleben V. Homo erectus - seine Kultur und Umwelt, zum Lebensbild des Urmenschen. Langenweißbach: Beier \& Beran. Archäologische Fachliteratur.

Muehlenbein, Michael P. Ed. (2015): Basics in Human Evolution. London: Elsevier Inc.

Niemitz, Carsten (2010): The Evolution of the Upright Posture and Gait. A Review and a New Synthesis. Naturwissenschaften, 97(3), 241-263.

Půtová, Barbora - Soukup, Václav Eds. 2015. The Genesis of Creativity and the Origin of the Human Mind. Prague: Charles University in Prague, Karolinum Press.

Rightmire, Philip (2010): Origins, Evolution, and Dispersal of Early Members of the Genus Homo. In: Larsen, Clark S. Ed. A Companion to Biological Anthropology. Oxford: Wiley-Blackwell, 441-356.

Rodman, Peter S. - McHenry, Henry M. (1980): Bioenergetics of Hominid Bipedalism. American Journal of Physical Anthropology, 52, 103-106.

Roberts, M. B. - Stringer, Christopher G. - Parfitt, Simon A. (1994): A Hominid Tibia from Middle Pleistocene Sediments at Boxgrove. Nature, 369, 311-313.

Senut, Brigitte - Pickford, Martin - Gommery, Dominique et al. (2001): First Hominid from the Miocene (Lukeino Formation, Kenya). Paris: Comptes Rendus des Seances de l'Academie des Sciences, 332, 137-144.

Simpson, Scott W. (2013): Before Australopithecus: The Earliest Hominins. In: Begun, David, R. Ed. A Companion to Paleoanthropology, Oxford: Wiley-Blackwell, 417-433.

Schoetensack, Otto (1908): Der Unterkiefer der Homo heidelbergensis aus den Sanden von Mauer bei Heidelberg. Leipzig: Wilhelm Engelman.
Shreeve, Jamie (2015): Záhadný člověk. National Geographic Česko, říjen 2015, 34-56.

Schrenk, Friedemann (2013): Earliest Homo. In: Begun, David R., Ed. A Companion to Paleoanthropology, Oxford, Wiley-Blackwell, 480-496.

Simpson, Scott W. (2010): The Earliest Hominins. In: Larsen, Clark S. Ed. A Companion to Biological Anthropology, Oxford: Wiley-Blackwell, 314-340.

Soukup, Václav (2015): Prehistorie rodu Homo. Praha: Karolinum.

Svoboda, Jiř́ A. (2014): Předkové: Evoluce člověka. Praha: Academia.

Tattersall, Ian - Schwartz, Jeffrey (2001): Extinct Humans. New York: Westview Press.

Tattersall, Ian (2012): Masters of the Planet: The Search for Our Human Origins. New York: Palgrave Macmillan.

Thoma, Andor (1972): Letter to Editor. Cranial Capacity, Taxonomical and Phylogenetical Status of Vértesszollos Man. Journal of Human Evolution, 1.5 , Vértes, László: Kavics ösvény.

Thoma, Andor (1972): On Vértesszollos Man. Nature, 236, 5348.

Thoma, Andor (1978): Some Notes on Wolpoff's Notes on the Vértesszollos Occipital. Journal of Human Evolution, 7, 4.

Vančata, Václav (2013): Paleoantropologie a evoluční antropologie. Praha: Nakladatelství Pedagogické fakulty Univerzity Karlovy v Praze.

White, Tim D. - Suwa, Gen - Asfaw Berhane (1994): Australopithecus ramidus: A New Species of Early Hominid from Aramis. Ethiopia. Nature, 371, 306-312.

Villmoare, Brian A. - Kimbel, William H. - Seyoum, Chalachew (2015): Early Homo at 2.8 Ma from Ledi-Geraru, Afar, Ethiopia, Science 6 March, 1056-1057.

Walker, Alan - Leakey, Richard E. F. Eds. (1993): The Nariokotome Homo erectus Skeleton. Cambridge: Harvard University Press.

Wolpoff, Milford H. (1971): Is Vertosszollos II an Occipital of European Homo erectus? Nature, 232, 5312

Wolpoff, Milford H. (1977): Some Notes on Verteszollos Occipital. American Journal of Physical Anthropology, 47 (3), 357-363

Wolpoff, Milford H. (1999): Paleoanthropology. Boston: McGraw-Hill.

Wood, Bernard A. (2011): Human Evolution. New York: Sterling Publishing Company.

Wood, Bernard A. (2011): Wiley-Blackwell Encyclopedia of Human Evolution. Chester, West Sussex, Hoboken, NJ: Wiley-Blackwell

Wood, Bernard A. - Schroer, Kes. (2013): Paranthropus. In: Begun, David R. Ed. A Companion to Paleoanthropology. Oxford, Wiley, 457-478.

\section{AUTHORS}

Soukup, Václav (31. 8. 1957, Mariánské Lázně) is a Czech anthropologist working at the Faculty of Arts, Charles University in Prague. $\mathrm{He}$ is the author of Prehistory of the genus Homo (2015), Anthropology: Theory of Man and Culture (2011) or History of Anthropology (2004). He teaches social and cultural anthropology, cultural studies and paleoanthropology, and is among the founders of the interdisciplinary cultural studies course that aspires to connect the human society and culture. Soukup is the author of numerous scientific papers and monographs devoted to the theory of culture, history and paleoanthropological thinking. His extensive book History of Anthropology was awarded the Rector's Prize of Charles University as the best publication in the field of social sciences in 2004

Contact: Doc. PhDr. Václav Soukup, CSc., Faculty of Arts, Charles University, nám. Jana Palacha 2, 11638 Praha 1,

e-mail: vaclav.soukup@ff.cuni.cz

Mechurová, Zdenka (14. 12. 1984, Komárno), a Slovak theorist of culture and anthropologist, who deals with the issue of applied anthropology and intercultural communication in her research and publishing activities. Other areas of her professional interest include painting.

Contact: Mgr. Zdenka Mechurová, PhD.,

e-mail: mechurova.zdenka@gmail.com 